\title{
Characterizing Spatiotemporal Patterns of Drought among the Pastoralists of Southern Ethiopia, Eastern Africa
}

Mekuria Guye ( $\nabla$ mekuriaguye@gmail.com )

Bule Hora University

Abiyot Legesse

Abiyot Legesse2

Yimer Mohammed

Dila University

\section{Research}

Keywords: RDI, Mann Kendall, Drought, Drought trends, Watershed, Guji, Pastoralist

Posted Date: March 1st, 2021

DOl: https://doi.org/10.21203/rs.3.rs-247346/v1

License: (c) This work is licensed under a Creative Commons Attribution 4.0 International License.

Read Full License 


\section{Characterizing Spatiotemporal Patterns of Drought among the Pastoralists of Southern}

\section{Ethiopia, Eastern Africa}

Mekuria Guye $^{1,}$ Abiyot Legesse ${ }^{2}$ and Yimer Mohammed ${ }^{3}$

1* Bule Hora University, Department of Geography and Environmental Studies, PhD candidate at Arba Minch University, Department of Geography and Environmental Studies Corresponding author: mekuriaguye@gmail.com,_P.O.Box 144

2* Dila University, Department of Geography and Environmental Studies abiyottura@gmail.com

3* Dila University, Department of Geography and Environmental Studies

yimermoh2013@gmail.com

\section{Abstract}

This paper is an inquiry of investigating trends and spatiotemporal patterns of meteorological drought in semi-arid pastoral areas in southern Ethiopia. Monthly gridded rainfall and temperature data for thirty years between 1986 to 2016 were obtained d from Ethiopian Meteorological Agency. Nonparametric Mann Kendall's test (MK) along with Sen's slope estimator was employed to see trends of drought. In addition, Reconnaissance Drought Index (RDI) was used to characterize the drought patterns. The result indicates that under all time scale, drought events tend to show an increasing trend with varying magnitude and intensity. The highest drought severity category for major and small rainy months was identified during May 2000 with $R D I=-2.28$ and September 2000 with $R D I=-2.55$. The drought magnitudes of the small rainy months range from -11.15 in November to -11.76 in September, while it ranges from -10.08 in April to -11.38 in March for the major rainy months. There are some variations of drought magnitude among the seasons while rainfall tend to show gradual decline as a manifestation of spatially varying drought severity, frequency and intensity in the watershed.

Keywords: RDI, Mann Kendall, Drought, Drought trends, Watershed, Guji, Pastoralist 


\section{Introduction}

Drought is an incessantly happening climatic phenomenon mostly related to the reduction of precipitation (Alok and Anil, 2018) and is time of prolonged below-normal supply of water (Rajib et al., 2013; Ndlovu and Brain, 2011). Although drought happens ubiquitously in the world; the intensity, frequency, severity and impacts vary spatiotemporally. The available estimates on drought impacts suggest that, during the period 1900-2013, there were 642 drought events reported across the world resulting in a huge toll to humanity, killing about 12 million people and affecting over 2 billion (Kiumars et al., 2016). There was a tremendous change in terms of its frequency, severity and geospatial coverage (IPCC, 2007; Shiau and Hsiao 2012 and Mishra and Singh, 2011). To this end, there are number of indications about projection of threats from the drought where the fatalities are also escalating. According to IPCC (2007) report drought is expected to expose between 75-250 million people to water stress by 2020 globally. By 2020, there will be a significant reduction in arable land in Africa, yields from rain-fed agriculture will decline by as much as $50 \%$, which worsens the need of food stuff (Oxfam, 2008).

Due to regional variability of rainfall, countries in Africa face varying drought incidences. The highest spatial and temporal variability of rainfall is found across most of the countries having a semi-arid climate within western, eastern and southern Africa (Misangi, 2014). Kenya has a tropical climate with two rainy seasons, one occurring in March, April and May and the second one in October, November and December (Peter et al., 2001 and Francis et al., 2015). Over $80 \%$ of the country falls under arid and semi-arid lands (ASAL) which are prone to droughts International Federation of Red Cross and Red Crescent Societies (IFRCRCS, 2014 and Francis et al., 2015). This can also be largely linked with the differences in intra-annual variability of the rain each region receives. Southern Africa receives most of the rainfall during OctoberMarch, whereas Sahel rainfall is concentrated during July-August summer monsoon period 
(Mavhura et al., 2013). The countries in the Horn of Africa usually receives rainfall in two seasons; October-December as short rainfall season and March-May a long rainfall season (Gebrehiwot et al., 2011; Georgis, 1997 and Seleshi and Camberlin, 2006). North Western Africa receives most of the rainfall during October to April (Temesgen, 2010).

In African countries there is variability and below average rainfall at regional basis, which gives birth to variation of drought severity and frequencies across the continent (Araya and Stroosnijder, 2011 and Agnew and Chappell, 1999). In the continent alone, the droughts that was occurred in 1972-1973, 1983-1984 and 1991-1992 were most intense and widespread (Masih et al., 2014). Regionally, Northern Africa receives very low rainfall and has a desert climate (Davies et al., 1991) in which the persistent dry years reduced societies coping capacity to droughts. Prolonged droughts were recorded in the recent past in 1999-2002 in northwest Africa and between 1970s-1980s in western Africa (Dembele and Zwart, 2016, Agnew and Chappell, 1999). From 2010-2011, there was drought with varying intensity recorded in eastern Africa (Degefu and Bewket, 2014; Degefu et al., 2017, and Gebrehiwot et al., 2011) and by 2001-2003 in southern and south eastern Africa (Masih et al., 2014 and Oxfam, 2008).

Being a country in the eastern Africa, Ethiopians has been facing different drought incidences with dozens of animal and human deceases. According to Zenebe et al., (2016), despite the fact that Ethiopia has a long history of drought, the frequency and spatial coverage of droughts have increased over the past decades since 1960s. Both the rise in temperature and prolonged deficiency of precipitation are major factors (Yuei and Getachew, 2019). The drought apparently escalated food shortages through declining agricultural productivity in the 1970s and 1980s (Terefe and Mengistu, 2012). The most severe drought Ethiopia faced was the 
notorious famines known as Kifuken ${ }^{l}$, which devastated major areas of the country during 1980s Ethiopian Environmental Authority (EEA, 1998). In the year 2002-2003 a drought resulted from El Niño occurred in Ethiopia which laid an overwhelming impact on the already vulnerable households, particularly in rural communities (Sujakhu et al., 2018). As a very recent history, during the year 2011, about 13.4 million people of the Intergovernmental Authority on Development (IGAD) region including Ethiopia, predominantly pastoralists and agro-pastoralists were affected by drought (Viste et al., 2013; MoA, 2012 and USAID, 2016).

Nowadays, drought incidences put pastoralism and agro-pastoralists livelihoods at high risk (MoA, 2012). During the years 1960-1990s, Ethiopia used to face drought frequencies every eight-ten years (Tsega, 1997), but now the time interval reduced to every five years and even below (Zenebe et al., 2016 and USAID, 2016). As vulnerability continued to increase, the impacts are similarly increasing for both pastoralist and farming community. There is continued failure of harvest far less than the expectations due to an extended extreme dry season and strong rain in the wet season, followed by a prolonged absence of precipitation, which is likely due to a manifestation of global warming (Gebrehiwot et al., 2011 and MoA 2012). The El Niño Southern Oscillation (ENSO) phenomenon hugely impacts Ethiopian rainfall (Peter et al., 2010; Camberlin, 1997 and Woldeamlak and Conway, 2007). It hugely resulted in uncertain drought. For instance, a drought crisis in Ethiopia, triggered by erratic and severely declined rainfall in early 2015, has affected 9.7 million Ethiopians (Roop et al., 2016). This in turn made pastoralism and pastoral livelihoods unsustainable. Moreover, this kind of situation created the cycle of vulnerability and depletes the capability to overcome hunger and poverty (Abate, 2013).

\footnotetext{
${ }^{1}$ is years of Ethiopian great famine from 1988-1892 which locally known as 'evil days'
} 
In the very recent time, the drought of $2015 / 16$ also troubled rural population mainly pastoral communities in southern and eastern parts of the country to the large extent. Thus, it is believed that the 2015 drought triggered price increases from August 2015 through to May 2016, with average nominal price increases of $5.7 \%, 16 \%$, and $15 \%$ for maize, sorghum and teff respectively, along with a $22.5 \%$ price increase for aggregate pulses (USAID 2016; Roop et al., 2016 and Yonas 2019). Meanwhile, Guji pastoralist in Southern Ethiopia, being economically and politically marginalized and already inhabited to drought sensitive environment, continued to live under drought continuum. Diminishing of pasture land and overpopulation reduced adaptive capacity to habitually occurring drought. Most of the drought responses are rarely proactive, building economically coping and adapting pastoralism has been challenging. The provision of pasture and water in very limited amount from their environment were managed through institutionally systematized pool of indigenous knowledge. This knowledge also gradually abandoned due to different pressures both from within and externally. The state plan which aimed to form sedentary life in pastoral area abandoned mobility. This in turn substantially restrained communal resource exploitation tradition that pastoralist used to practice for the time immemorial. The activities of buildingup solid resilient pastoral community which easily survive drought and other climate related hazards were not met. Traditionally, pastoralists were defending champions when they used to follow institutionally managed ploy of utilizing scarce resources. Under all this complexities, identifying trends and spatial patterns of drought helps intervene drought incidences and limit impacts. Thus, the aim of this paper is to analyze trends and spatiotemporal variation of drought in Burkitu watershed of Guji zone in southern Ethiopia.

\section{Materials and Methods}

\section{Description of the Study Area}


Dugda Dawwa Woreda is found in Eastern Guji zone Oromia regional state. It is one of the woredas of the Eastern Guji zone with area coverage of mentioned to be $2180 \mathrm{~km}^{2}$. Fincawa is the capital town of the woreda which is located at about $500 \mathrm{~km}$ from Addis Ababa and 25 kms from Bule Hora, the capital town of the zone. It is mainly inhabited by pastoralists with very small number of agro-pastoral households. Agro-ecologically, the area is known for its arid and semi-arid climate. The mean maximum and minimum temperature of the area is $27^{\circ} \mathrm{c}$ and $17^{\circ} \mathrm{c}$, respectively. The study area receives bimodal rainy season with $60 \%$ occurring in the spring $\left(\right.$ Ganna $\left.^{2}\right)$, which occurs from March to May and in the autumn (Hagayya ${ }^{3}$ ) reaches the area starting from September-November. The long dry season (Bona Hagayya) occurs from December to February in the Winter followed by the short dry season (Adoolessa) occurs from June to August in the Summer season. In the district, the average annual rainfall ranges between 350 and $850 \mathrm{~mm}$, with considerable spatial and temporal variability. Inconsistent rainfall results in great variability of forage and range production.

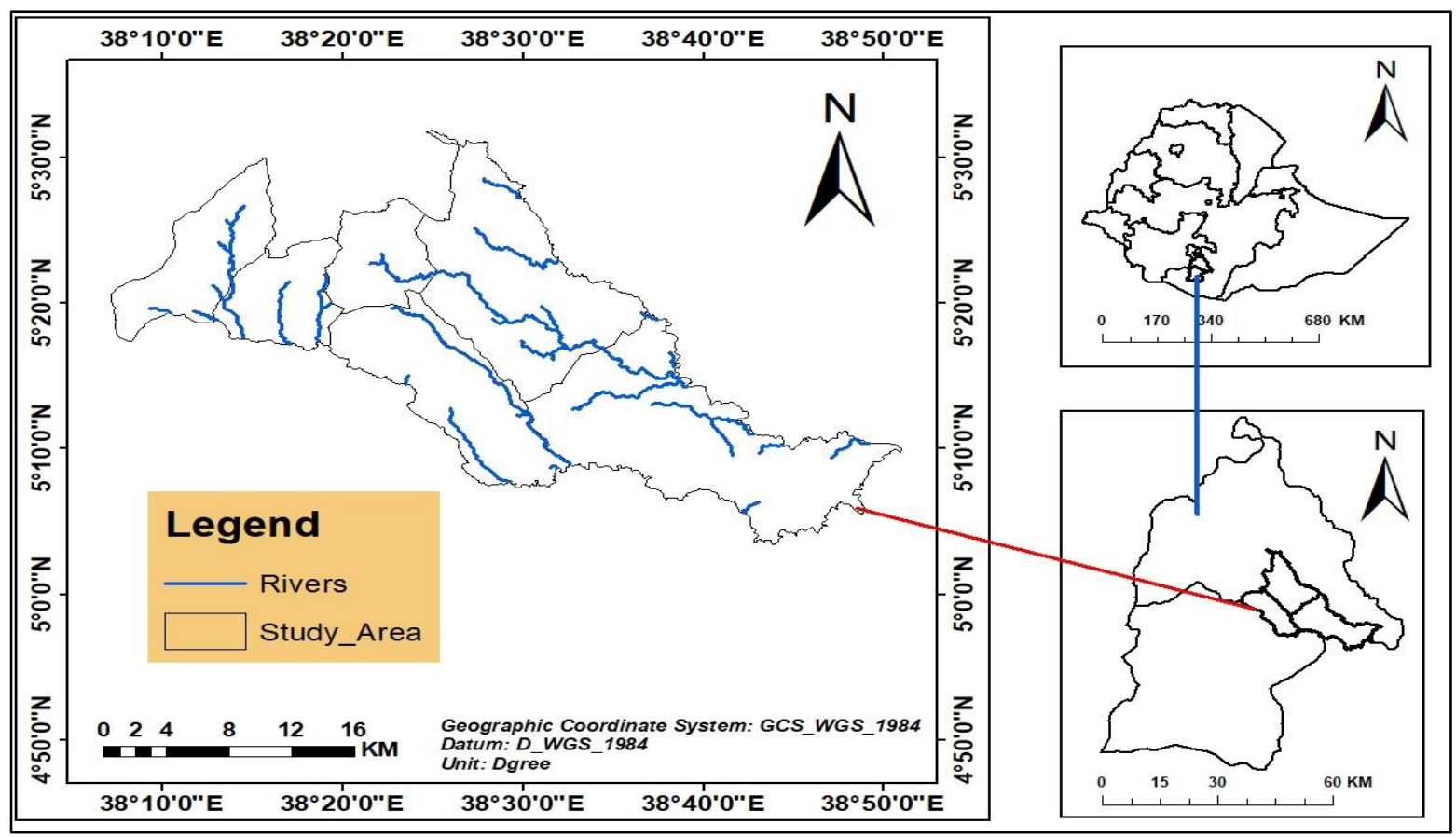

Fig 1 Location Map of the Study Area

\footnotetext{
2 Ganna is local name given to the time of relatively long rainy season

3 Hagayya is local name to short rainy season
} 
In few areas of the district, agricultural crops like maize, teff, sorghum and haricot beans are produced. It is estimated that $55.4 \%$ of the income in the zone is derived from the sale of livestock. The main livestock being reared are cattle, sheep, goats, sheep and camels. Cattle contribute much to the milk for home consumption and butter production used both for consumption and sold at market. Subsistence agriculture also contributes to a lesser extent to food needs in the district. Beside this, bee keeping practice and crop production activities in the high land areas of the district practiced in limited custom. In the very recent time, rearing livestock becoming challenge due to degradation of range land, population pressures, water shortage, recurrent drought and livestock diseases. In addition, petty trades are highly practiced at Finchawa town and few kebeles nearby to the town. Similarly, sale of livestock, production and sale of vegetables, charcoal, firewood, water, minerals (such as gold, marble and granite), incense and natural gum were common in the study area.

\section{Data sources and acquisition}

Drought analysis in this paper was holistically focused on investigating trends, magnitude, severity, intensity and spatial pattern in the watershed. Basically, calculations of drought pattern were based on the long-term meteorological data that were acquired from Ethiopian National Meteorological Agency (ENMA) for the year 1986-2016. Therefore, gridded data of rainfall and temperature were taken for thirty years and calculations were made for different time (1-month, seasonal and annual) scales.

\section{Drought Indices}

In drought characterization based on its magnitude and spatial analysis, different indices can be used. In the arid climate, Standardize Precipitation Index (SPI) and Reconnaissance Drought Indexes (RDI) are most commonly used. They are recommended to quantify the deficiency of 
precipitation at different time scales and across space (Kumar and Anil, 2018; Melaku, 2013; Oloro, 2006 and Alok and Anil, 2018). Often times, SPI criticized for it fails to precisely quantify drought condition of prolonged time over the areas with scarce rainfall. This is due to it solely uses precipitation as an input and not considering temperature and its influences. Others suggest, SPI is computed for shorter-term and intermediate periods to quantify drought in different time steps to represent agricultural/meteorological droughts (Abebe et al., 2020). Thus, SPI is less preferred to be used for drought analysis in the case of extreme droughts (over longer period) occur with same frequency on all locations (Tsakiris and Vangelis, 2005). It can't identify drought prone regions and areas with small seasonal precipitation for the values might be large positive or negative which would be terribly misleading (Jemai et al., 2016). Therefore, in the areas where temperature is high throughout the year and rainfall is inconsistently received annually, RDI is appropriate for it considers potential evapotranspiration (PET). Therefore, RDI is a meteorological index used for drought assessment (Mohammad et al., 2011; Mohammed et al., 2018 and Zarch et al., 2011) and it was developed to analyse water deficit in a more accurate way, as a sort of balance between input and output in a water system (Tsakiris et al., 2007c). Moreover, RDI can be effectively used to compare the drought conditions between areas with different climatic characteristics (Haied et al., 2017). It also has an advantage as it enables universal applicability over the other indices (Haied et al., 2017). By employing monthly or seasonal measures of PET from the general index of meteorological drought, extent of drought spatial pattern and severity for different time scale over the space can be mapped. Therefore, as the area under study is categorized under an arid climate, RDI were used to characterize the drought.

\section{RDI computation}

The RDI is expressed in three forms namely, the initial value ( $\alpha \mathrm{k})$, normalized RDI (RDIn) and standardized RDI (RDIst) (Tsakiris and Vangelis, 2005). The initial value ( $\alpha \mathrm{k})$ is presented 
in an aggregated form using a monthly time scale and be calculated on a monthly, seasonal or annual basis. Concerning the values, positive values of the RDIst indicates wet periods, whereas the negative values indicate dry periods compared with the normal conditions of the area. The computation of RDI was done by using Drinc Software which is based on the ratio of total precipitation $(\mathrm{P})$ to potential evapotranspiration (PET) accumulated over the selected time scale $(\mathrm{k})$. On the annual basis $(\mathrm{k}=12)$, we have:

$\alpha^{(i)}=\frac{\sum_{j=1}^{12} P_{i j}}{\sum_{j=1}^{12} P E T_{i j}}$

Where Pij and PETij the precipitation and potential evapotranspiration of the $\mathrm{j}$-th month of the i-th year.

The standardized RDI is computed by:

$R D I_{(k)}^{(i)}=\frac{y_{(k)}^{(i)}-\overline{y_{k}}}{\sigma_{y k}}$

with $\mathrm{y}^{(\mathrm{i})}=\ln \left(\mathrm{a}^{(\mathrm{i})}\right), y k$ arithmetic mean and $\sigma_{y k}$ standard deviation.

The Hargreaves equation can be written as:

$P E T=0.0023 R a(T+17.8) \sqrt{(T \max -T \min )}$

where PET is the computed reference evapotranspiration $\left(\mathrm{mmd}^{-1}\right)$; while $\mathrm{Ra}$ is the water equivalent of the extraterrestrial radiation $\left(\mathrm{mm} \mathrm{d}^{-1}\right)$. Similarly, Tmax, Tmin and $\mathrm{T}$ are the monthly maximum and minimum temperature in $\left({ }^{\circ} \mathrm{C}\right)$, with $\mathrm{T}$ calculated as the average of 
Tmax and Tmin, where 0.0023 is the original empirical coefficient proposed by Hargreaves and Samani in 1985 (Seleshi and Camberlin, 2006).

According to Tsakiris et al., (2015), drought can be grouped in to different category based on the RDI values. An example for development of the ak relationship and fixing of ranges for drought classes is illustrated for Burkitu watershed in Dugda Dawa district. Using this relationship, the levels of drought have been fixed based on $\alpha \mathrm{k}$ for Burkitu Watershed and given below in the (Table 1).

Table 1: Drought level characterization based on RDI value

\begin{tabular}{lll}
\hline Number & Drought category & RDI value \\
\hline $\mathbf{1}$ & No drought & $>-0.50$ \\
$\mathbf{2}$ & Mild drought & -0.50 to -1.0 \\
$\mathbf{3}$ & Moderate drought & -1.00 to -1.50 \\
$\mathbf{4}$ & Severe drought & -1.50 to -2.0 \\
$\mathbf{5}$ & Extreme drought & $<-2.0$ \\
\hline
\end{tabular}

Source: Alok and Anil, 2018.

\section{Characterizing drought events: Magnitude, Intensity and Severity}

The analysis of the drought trend was done using a non-parametric Mann Kendall (MK) test.

The rank-based MK test is commonly used to assess the significance of monotonic trends in hydro meteorological time series (Mohammed et al., 2018; Mekonnen and Woldeamlak, 2014 and Tabari, 2011). In the process of computation, determination of trend was run by taking values of Reconnaissance Drought Index (RDI). MK test was used by many researchers for trend detection (Kendall, 1975 and Mohammed et al., 2018). It is widely used to detect trends 
of meteorological variables (Mekonnen and Woldeamlak, 2014). It has two advantages and thus preferably used by different researchers. First, MK test does not require the data to be normally distributed and secondly, it has low sensitivity to abrupt breaks due to inhomogeneous time series (Tabari, 2011). It entails an assumption of either increasing or decreasing trend in the element (data). According to this test, the null hypothesis, $\mathrm{H}_{0}$ assumes that there is no trend (the data is independent and randomly ordered) and this is tested against the alternative hypothesis $\mathrm{H}_{1}$, which assumes that there is a trend (Neha, 2012). In the analysis of trends of drought in observed rainfall time-series (1-month, seasonal and annual) was calculated on annual and seasonal basis. The M-K test statistic $\mathrm{S}$ is calculated using the following formula:

$\sum_{i-1}^{n-i} \sum_{j-i+1}^{n} \operatorname{sgn}\left(x_{\mathrm{j}}-x i\right)$

Where, $x i$ is the data time series ranked from $i=1,2, \ldots n-1$; and $j=2,3 \ldots . n$. Each of the data point $x i$ was taken as reference point, which is compared with the rest of the data points, $x j$ :

$\operatorname{sgn}\left(x_{\mathrm{j}}-x i\right)=\left\{\begin{array}{l}-1 \text { for } x_{\mathrm{j}}<\mathrm{xi} \\ 0 \text { for } \mathrm{x}_{\mathrm{j}}=\mathrm{xi} \\ 1 \text { for } \mathrm{x}_{\mathrm{j}}>\mathrm{xi}\end{array}\right.$

A positive value of $S$ indicates increasing trend, and a negative value indicates decreasing trend. It has been documented that when $\mathrm{n} \geq 8$, the statistic $\mathrm{S}$ is approximately normally distributed with the mean zero and variance computed as:

$\operatorname{Var}(S)=\frac{n(n-1)(2 \mathrm{n}+5) \sum_{i=1}^{m} t \boldsymbol{i}(t \boldsymbol{i}-1)(2 t \boldsymbol{i}+\mathbf{5})}{18}$

Where, $\mathrm{m}$ is the number of tied groups and ti is the number of ties in sample $\mathrm{i}$.

The normal test statistic ZMK is computed as:

$Z_{M K}\left(= \begin{cases}\frac{S-1}{\sqrt{\operatorname{VAR}(S),}} & \text { if } S>0 \\ 0 & \text { if } S=0 \\ \frac{S-1}{\sqrt{\operatorname{VAR}(S),}} & \text { if } S<0\end{cases}\right.$ 
The trend is said to be increasing, if ZMK is positive and computed ZMK statistic is greater than the ZMK value corresponding to a desired level of significance $(0.01,0.05$ or 0.10$)$; and the trend is said to be decreasing, if ZMK is negative and computed ZMK statistic is greater than the ZMK value corresponding to desired level of significance (Mekonnen and Woldeamlak, 2014). The Sen's slope estimator has been found to be a better and more power tool as compared to simple linear regression to detect the linear trend as it is unaffected by gross data errors and outliers (Kumar and Anil, 2018). The Sen's slope is estimated as the median of all pair-wise slopes between each pair of points in the data set. The pair-wise slope Ti of all data points is computed as:

$T i j=\frac{x_{\mathrm{j}}-x i}{\mathrm{j}-\mathrm{i}}$

Where, $x j$ and $x j$ are data values at the times $i$ and $j(j>i)$, respectively. For $n$ values in data set, there will be $\mathrm{N}=\mathrm{n}(\mathrm{n}-1) / 2$ number of slope estimates, and the median of these $\mathrm{N}$ values of Tij is represented as Sen's estimator of slope (Qi), which is calculated as:

$\mathrm{Qi}=\mathrm{T}(\mathrm{N}+1) / 2$, if $\mathrm{N}$ is odd

And

$\mathrm{Qi}=1 / 2(\mathrm{TN} / 2+\mathrm{T}(\mathrm{N}+2) / 2)$, if $\mathrm{N}$ is even

Positive value of Qi indicates an increasing trend, while a negative value indicates a decreasing trend. In characterising temporal drought events, frequency, severity, magnitude and intensity were computed. In this analysis, drought frequency is a return period between drought events that have negative values of RDI. In Abebe et al (2020) drought magnitude is a drought event corresponds to the cumulative water deficit during the drought period below some threshold (RDI-values $\geq-1$ ) and drought intensity is the ratio between drought magnitude (DM) and duration (DD) of the event given as:

$\mathrm{DM}=-\sum_{i=j}^{n} R D I i j$ 
$D I=\frac{\mathrm{DM}}{D d}$

Where: $D_{M=}$ is drought magnitude, $n=$ number of months with drought event at $\mathrm{j}$ time step, $\mathrm{Dd}=$ is drought duration.

\section{Mapping spatial distribution of drought incidences}

The RDI values produced by DrinC software were used as an input to ArcGIS to generate drought severity maps for the study area at 1,3 and 12-month time scales. To assess the spatial extent of droughts in the study area, RDI time series values were interpolated by Ordinary Kriging method using the Spatial Analyst tool of ArcGIS. Kriging refers to a surface interpolation technique based on spatially dependent variance (Webester and Oliver, 2007).

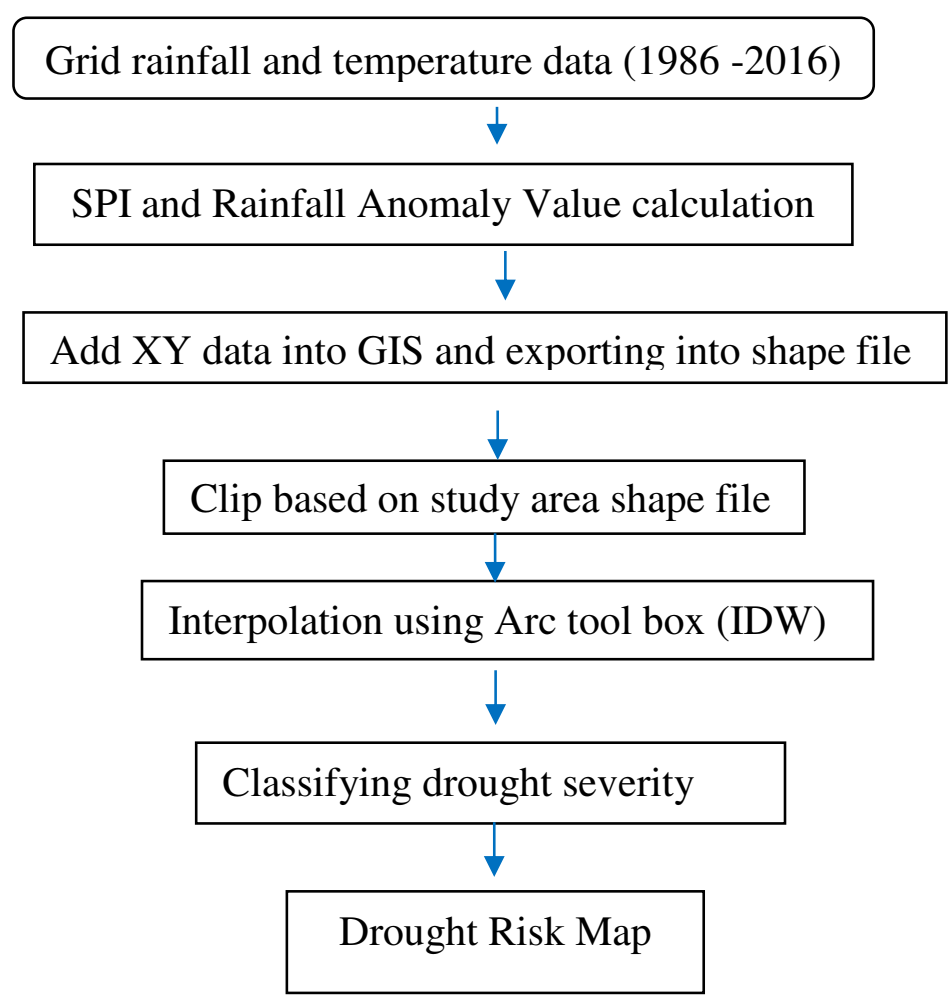

Zarch et al., (2011) classified drought severity as no drought $>-0.5$, mildly drought -0.5 to 1.0, moderate drought -1.0 to -1.50 , severely drought -1.50 to -2.00 and extreme drought less than -2.0 . 


\section{Result and Discussion}

\section{Characterizing Drought Events: Magnitude, Intensity and Severity}

In characterizing drought events using RDI, drought conditions for rainy months for different time scale (1-month, 3-month/seasonal and 12-Months/annual) was examined for the period 1986-2016. Varying drought events with different magnitude, intensity and severity were observed (Table 1). Both main and small rainy months had moderate drought intensity category in April with value of RDI $\leq-1.26$ and September with RDI -1.30 respectively.

Table 2: Drought event characteristics for rainy months of $\mathrm{RDI} \leq \mathbf{- 0 . 5}$ values

$\begin{array}{lllll} & \text { Drought } & \text { Drought } & \text { Drought } & \text { Years of observation } \\ \text { Time scale } & \text { Magnitude } & \text { Intensity } & \text { Severity } & \\ \text { March } & -11.38 & -1.13 & -1.67 & 1986,1992 / 3 / 9 / 00 / 01 / 02 / 04 / 10 / 16 \\ \text { April } & -10.08 & -1.26 & -1.99 & 1986,1992 / 97 / 99 / / 00 / 01 / 02 / 04 \\ \text { May } & -11.32 & -1.25 & -2.28 & 1986,1992 / 93 / 95 / 99 / 00 / 01 / 02 / 16 \\ \text { September } & -11.76 & -1.30 & -2.55 & 1986,1992 / 95 / 99 / 00 / 01 / 03 / 10 / 16 \\ \text { October } & -11.64 & -1.16 & -1.86 & 1992 / 3 / 96 / 99 / 00 / 01 / 03 / 09 / 10 / 16 \\ \text { November } & -11.15 & -1.11 & -1,82 & 1992 / 96 / 98 / 99 / 00 / 01 / 03 / 09 / 10 / 16 \\ \text { Spring (Mar-May) } & -24.9 & -3.55 & -2.56 & 1993 / 98 / 01 / 09 / 10 / 12 / 16 \\ \text { Autumn (Sep-Nov) } & -29.87 & -4.26 & -2.54 & 1992 / 99 / 00 / 01 / 03 / 10 / 16, \\ \text { Annual } & -11.76 & -1.68 & -2.55 & 1991 / 98 / 00 / 2 / 9 / 15 / 16\end{array}$

At 3-months (seasonal) time scale, Spring and Autumn had a total drought severity of -2.56 and -2.54 respectively. For Spring season, March was identified as a month with highest drought frequency and high drought magnitude. Showing little differences among seasons, the drought magnitudes of the small rainy months range from -11.15 in November to -11.76 in September, while it ranges from -10.08 in April to -11.38 in March for the major rainy months. 
The total drought events for the main rainy season are relatively lower as compared to the small rainy months. However, for the rain of small rainy months in the region is apparently inconsistent, strong drought with high RDI value is often commonly identified. Thus, duration of drought event is higher for small rainy months than the main rainy months. Annually, the year 2000 showed the highest drought manitude and severity with RDI value of above -2.0 . The highest drought severity category for major and small rainy months was identified for May 2000 with $\mathrm{RDI}=-2.28$ and September 2000 with $\mathrm{RDI}=-2.55$ respectively.Thus, the complexity and persistent drought events for small and main rainy months and seasons played a significant role in determining harvested water and the rate of pasture growth in the area respectively. In April, the severe drought category was identified in the year 2001 and 2016 while extreme drought was observed in the year 2012. At seasonal time scale (3-month), for belg (spring), there was a lower drought intensity but higher drought severity as compared to Autumn. Due to the lesser moisture in the months from December to February which proceeds the belg season, rain was highly affected as aridity increases in these months which tend to increase drought magnitude and severity. Moreover, the long dry season (Bona Hagayya) occurs from December to February play a significant role over the rain pattern in the area. Ostensibly, holding a drought magnitude of -24.9 , drought intensity of -3.55 and severity of -2.56 , belg season of the entire years had experienced spatiotemporally varying drought distribution in the the watershed. Cognizant to this, in pastoral zones observed rainfall declines during the belg season is reducing the quantity and quality of viable pasturelands (USAID 2012, Oxfam 2008 and Boku 2010).

\section{Temporal drought variation}

The drought condition for rainy months (main and small) of thirty years in different time scale, covering the period of 1986-2016 calculated. From the computation, a mix of dry and wet years 
has been observed. From the computation, several drought risk incidences with RDI $\leq-1.00$ were detected. For both rainy seasons Spring and Autumn, the year from 1999-2000 was the driest in the history of drought in the study area. For the main rainy months, March, April, and May as well as spring (belg) season has shown temporal variation with varying severity and intensity (Fig 2). For instance, May 1986 and 1992 were characterized by severe drought events with RDI $\leq-1.5$ while spring season of 2000 were characterized by extreme drought event. Similarly, in 1-month RDI, March of the year 1986, 2001 and 2004 and April of the year of 1992, 1999 and 2000 shows a drought of severe category respectively. Month of May in 1986 and 1992 showed severe drought while May of the year 2000 identified for extreme drought severity. At seasonal (3-months RDI), the years of 1986 and 2000 showed extreme drought category with little variation in magnitude.

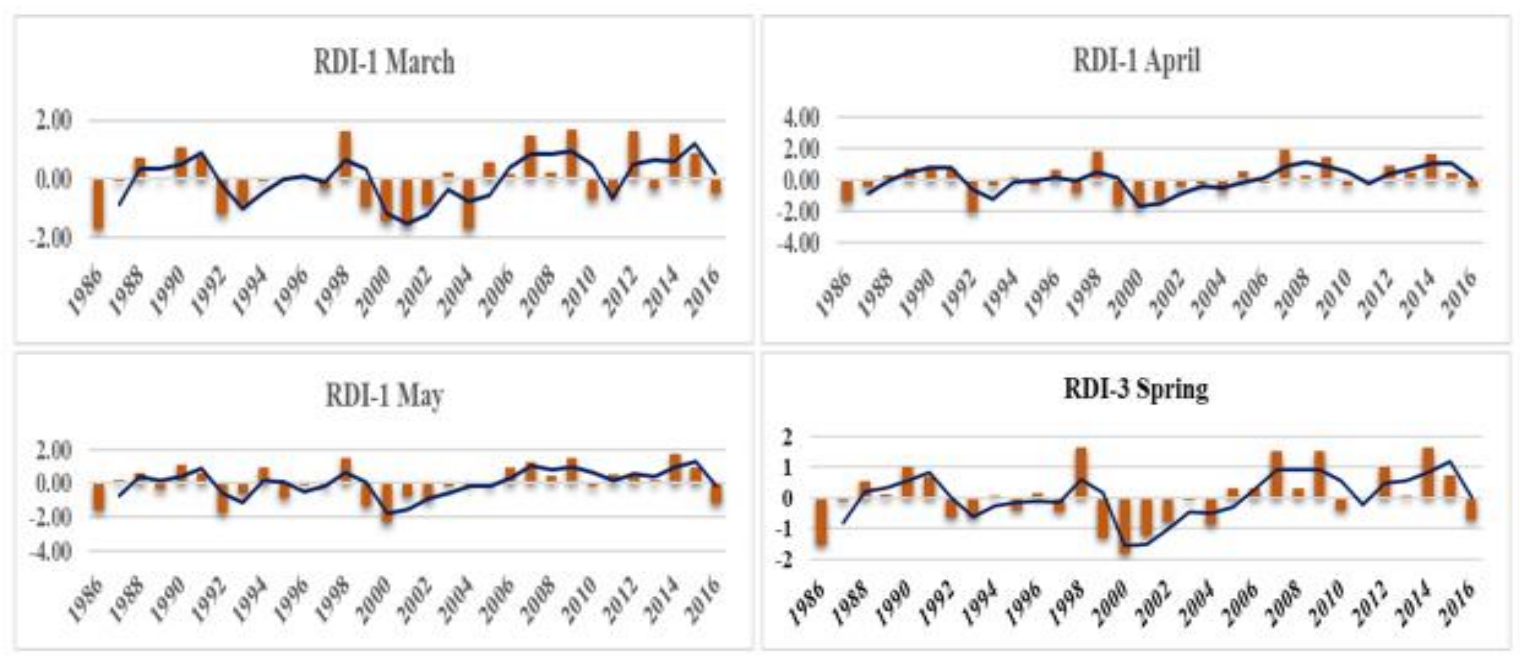

Fig: 2-Month and Seasonal RDI for Spring 


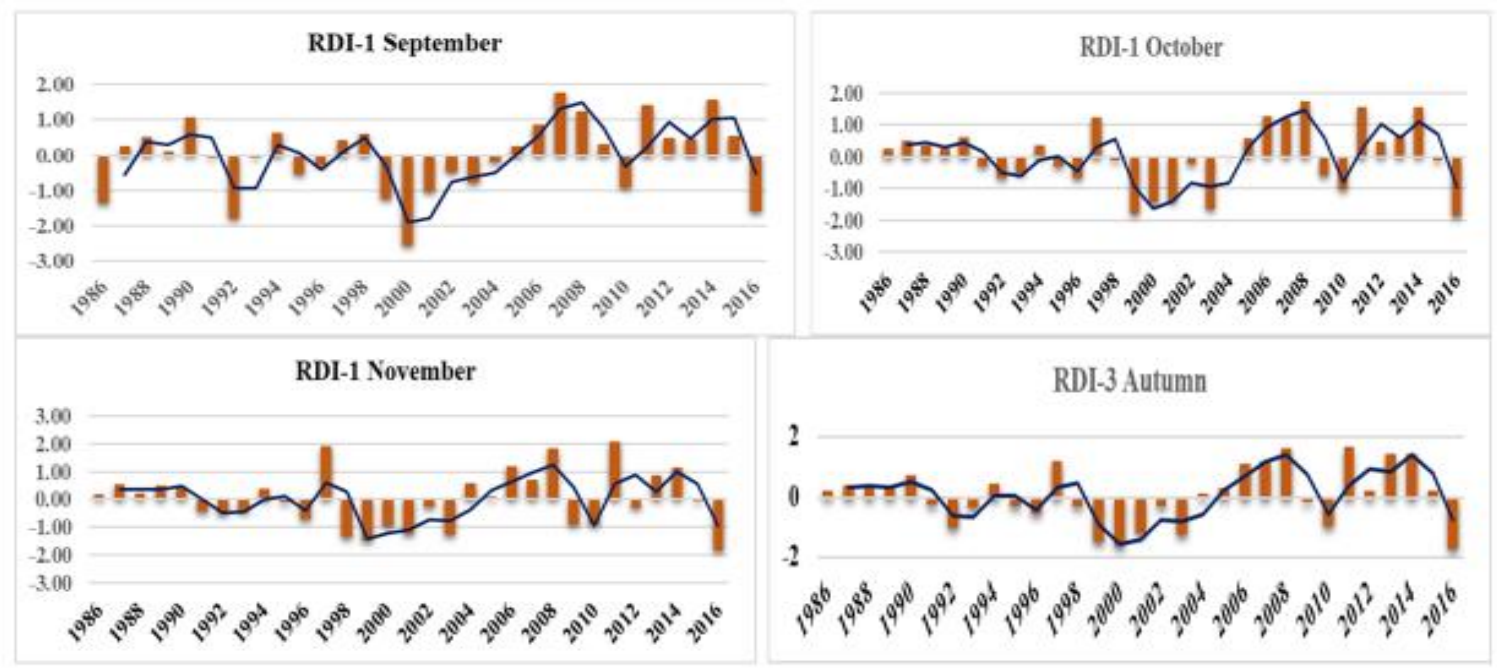

Fig: 3-Month and Seasonal RDI for Autumn

RDI for small rainy months also shows some temporal variations. In 1-months RDI for small rainy seasons September of the year 1992 and 2016 identified for severe drought while it showed extreme drought category in the year 2000. Similarly, in the October, for the year 1999, 2003 and 2016 identified as months with severe drought category. In the month of November, only the year 2016 identified for severe drought while season of the small rainy season (Autumn) showed severe drought category in the years 1999, 2000 and 2016. Rain condition for small rainy months and the autumn season is also impacted by the short dry season (Adoolessa) occurs from June to August in the area. In sum, temporal variation of drought is slightly higher for small rainy season.

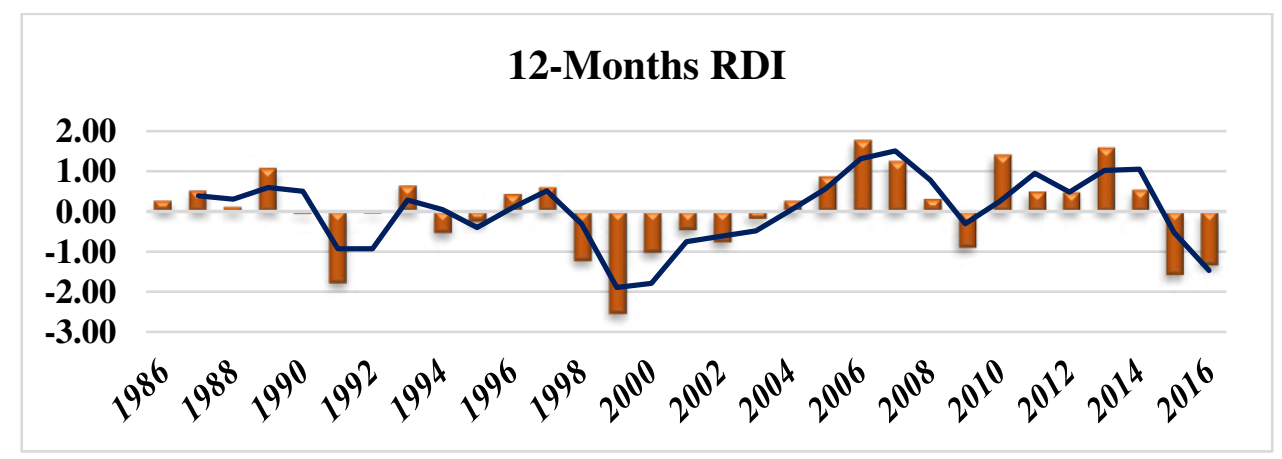

Fig 4: 12-Month (Annual) RDI 
RDI for annual time scape shows some temporal variations with relatively exceeding magnitue and intensity than that of 1-month and seasonal time steps. Severe drought once happened in 1991 and didin't happened since 1998. In the 1998, rainfall started to readily decline and resulted to the occurrence of extreme drought in 1999 which stayed for two years untill it ends in eventually in 2002. In the very recent time, the drought of 2015/16 was a disasterous in its kind which killed majority of livestock in the pastoral areas of southern Ethiopia mainly Guji, Borana, Gari and some Somali districts. Due to the absence of the rain in the main rainy season of the area, in the year 2016 severe drought was seriously hit the area and almost much of the harvested water was dried up and pasture scarcity prevailed. Evidently, the small rainy seasons that expected to reach the area in September of the year 1991/2 was lately arrived and resulted in severe drought which affected crop production that produced in some parts of the watershed mainly upper part.

\section{Drought Trends}

Table 3. Mann-Kendall's trend test for the rainy months of 1,3 and 12-months timescale

\begin{tabular}{llcc}
\hline Timescale & Months & MK test & Slope \\
\hline 1-Month & March & 1.16 & 0.022 \\
& April & 1.46 & 0.031 \\
& May & 1.50 & 0.039 \\
& September & 1.33 & 0.027 \\
& October & 0.41 & 0.009 \\
& November & 0.07 & 0.003 \\
3-Months & Spring (March-May) & 1.27 & 0.025 \\
& Autumn (September-November) & 0.56 & 0.015 \\
& January-December & 0.95 & 0.01 \\
\hline
\end{tabular}


Trends of the drought was examined using Mann Kendall and Sen Slope estimator for the years between 1986-2016. Incidences of drought trends for the small and big rainy months (RDI-1) and seasons (RDI-3 and RDI-12) timescales were shown in (Table 3). The Mann-Kendall trend test of RDI-values for all 1-months, 3-months and 12-months tends to shows a tendency of increasing trend. From the computation, it can be identified as very severe drought is occurring every 3-5 years and stay for two years. As compared to severe drought, the frequency of extreme drought is relatively low for both seasonal and annual time scale. For 1-month and seasonal time scale, the magnitude and intensities of drought incidences are increasing while its repeating period is witnessing gradually shortening. Evidence from Borana pastoralists also suggests that drought cycles have shortened from 5-10 years to 3-5 years (Boku 2010 and Oxfam 2010). In most pastoralist inhabiting parts of southern Ethiopia, drought is repeatedly occurring and highly influencing growth of pasture and water availability. Within the watershed alone, the spatiotemporal variability continued to affect pastoralist livelihood, pasture growth and water availability as the matter of degree of the stress. Water and pasture scarcity is already becoming a daily witness in the area which gave birth to the death of livestock and livelihood insecurity and calls for better interventions. Abbarufa (2011) highlighted that, previously drought has occurred once in Gada period (every eight years) and recently however, its magnitude and frequency is increasing from time to time (Bekele 2013). In pastoral communities of Ethiopia, climate-induced shocks such as droughts, rising temperature and irregular rainfall, reduced the availability of pasture areas and negatively impacted water availability and led to animal deaths owing to hunger and diseases (Angasse \& Oba 2007 and Boku 2008).

As it was mentioned earlier, it was examined that, the year 1999-2000/1 was the years with extreme drought over -2.0 which led to over $80 \%$ of livestock death Angasse \& Oba (2007) in 
Borana and Guji pastoral areas. Similarly, the years from 1991-1992 and 2015 identified as the time of severe drought in the area. In Burkitu Watershed in particular and pastoral nearby in general, the drought of 2015/16 alone resulted in number of livestock death. During such droughts, most of pastoralists lost their entire livestock because of the stresses associated with impacts of drought, forage/grasses and water scarcity (Hesse and MacGregor, 2006). A survey conducted in southern pastoral areas in 2009 found that drought occurred in the district every 1-2 years, compared to every 6-8 years in the past, evidence that the area is vulnerable to stresses related to Droughts (Riché et al., 2009).

\section{Mapping spatial patterns of drought incidences}

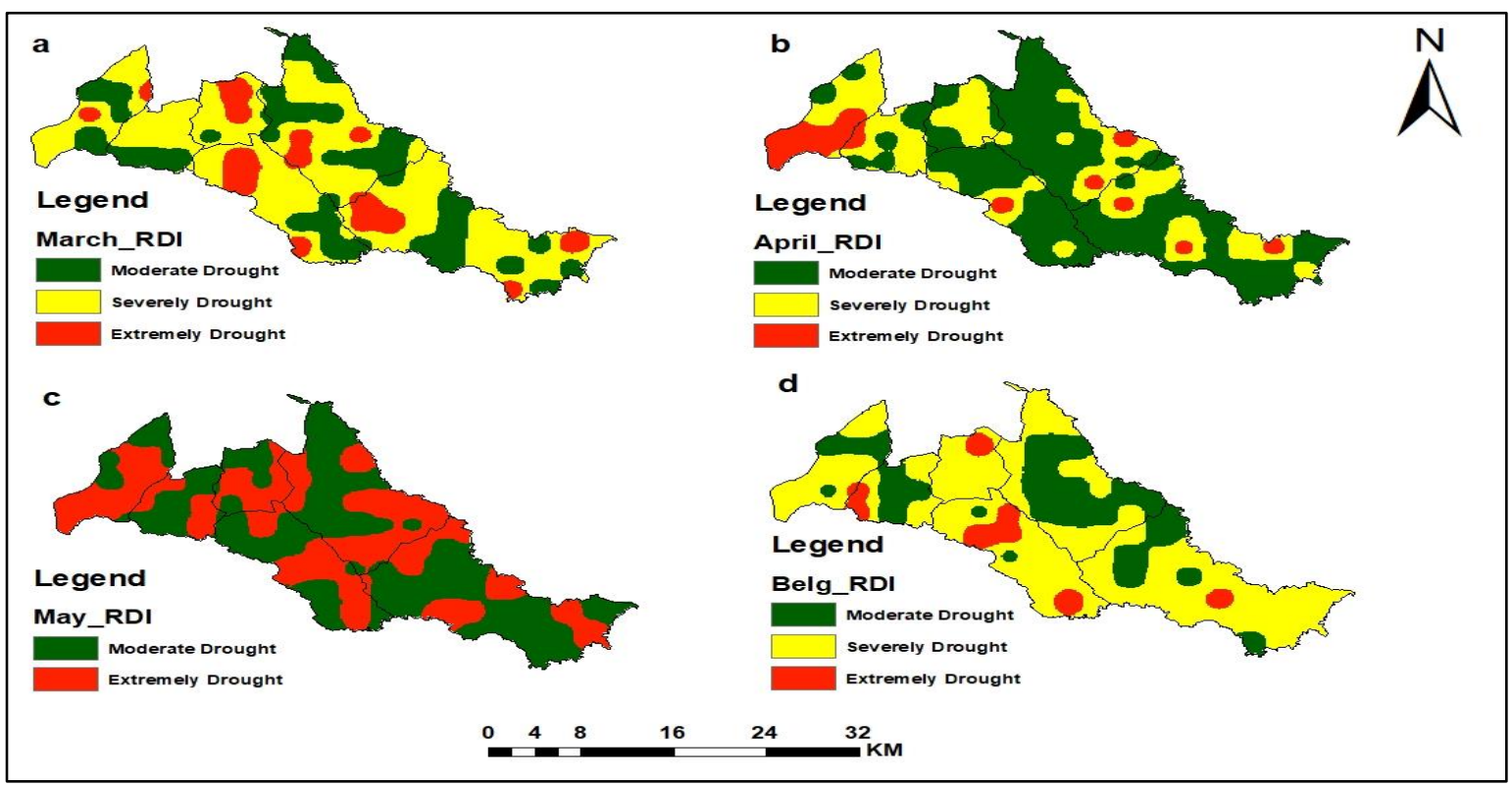

Fig 5: Spatial pattern of 1-month and 3-month (Spring Season) RDI

Thirty years (1986-2016) RDI was calculated and different classes of drought categories that varying spatially within the watershed unit (upper, middle and bottom) was identified. Within the watershed, 1-month (March, April and May) and 3-months Spring (Belg) RDI shows spatially varying in terms of magnitude, severity and spatial coverage. For 1-month and seasonal time scale, a drought varying from moderate to extreme category was observed. April 
was identified for severe drought that unevenly distributed across watershed unit. Similarly, month of May has shown extreme drought in central (middle) and upper parts of the watershed while few parts of southern tip and pocket areas in the uper part tend to posess moderate drought. Belg season shows severe drought category that covers al most whole parts of the watershed where extreme and moderate drought category was identified in few pocket areas of the watershed. In sum, for both 1-month and seasonal time scale, extreme drought incidences was observed.

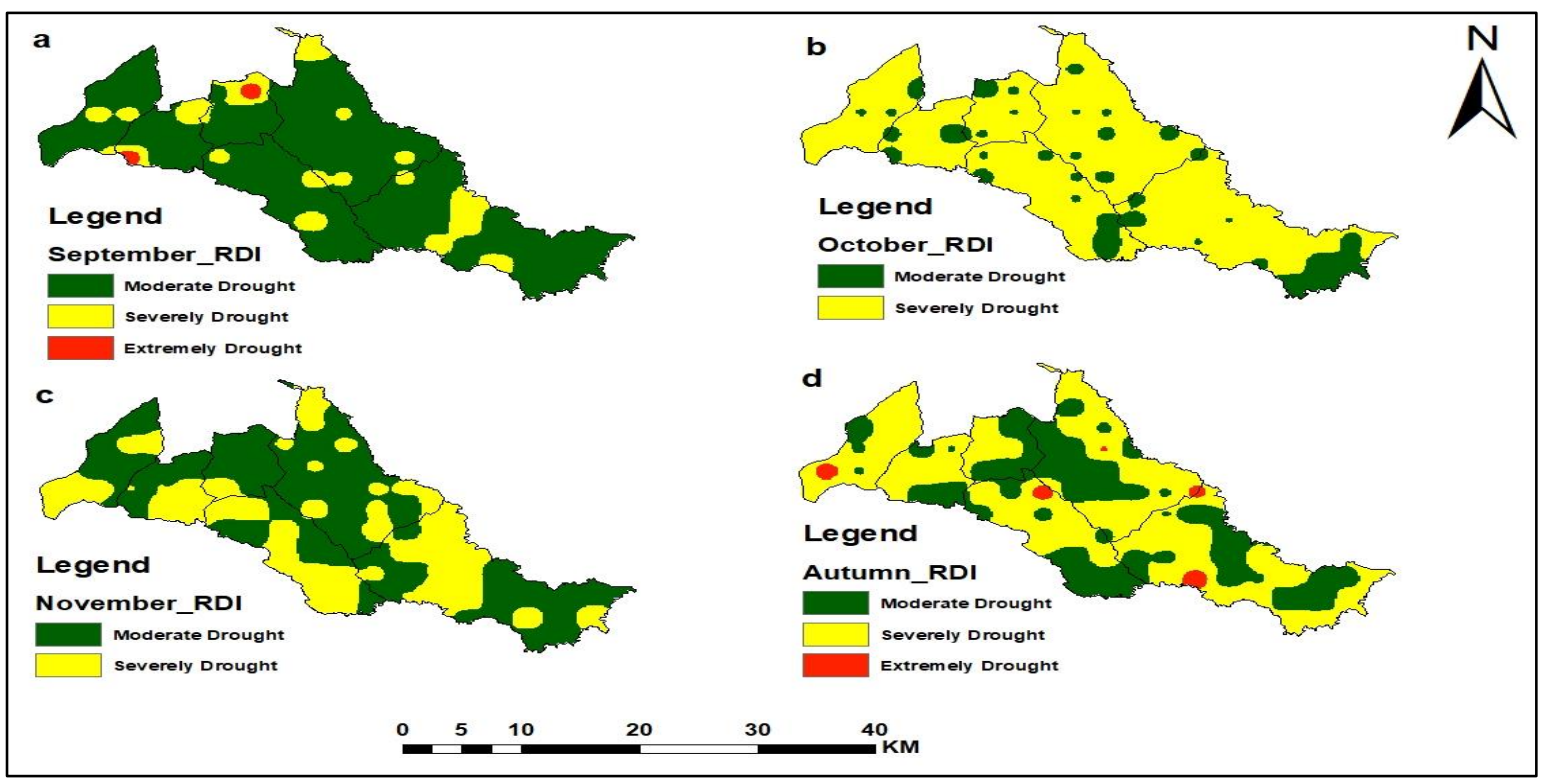

Fig 6: Spatial pattern of 1-month and 3-month (Autumn Season) RDI

For the small rainy season Tseday (Autumn), RDI of 1-month (September, October and November) and 3-month season also calculated. In 1-month RDI, Septemebr was observed as a month with moderate drought category that covered majority of the watershed unit while October is the month with severe drought category that nearly covered the whole watershed unit (Fig 6). During November, the whole areas of the watershed identified to exhibit only moderate and severe drought category. At seasonal time scale, a drought of varying severity category from moderate to extreme was identified across different watershed unit with varying magnitude. Large areas of the watershed was covered by severe drough while few areas of the 
watershed experienced extreme drought. In comparative view, Autumn shown the lowest extreme drought as compared to Spring due to the fact Belg rainfall was highly influenced by long dry seasons Bega (winter) which takes place from December to February. However, it was observed that Belg season identified for its relatively low drought frequency of only $16.6 \%$ of the total drought years while Tseday (Autumn) appeared to relatively have higher drought frequency of about $23.3 \%$ of the total years.

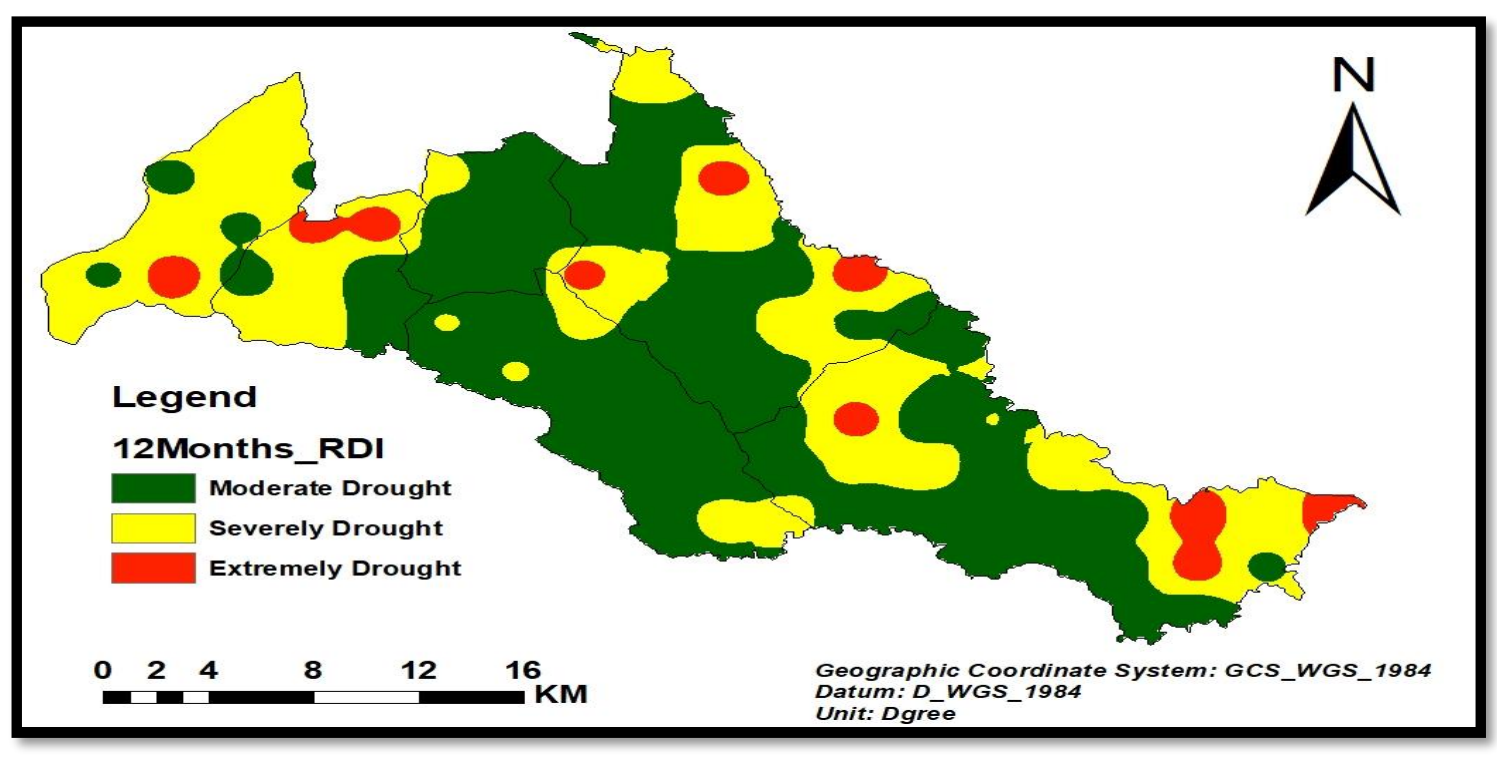

Fig 7: Spatial pattern of 12-month (Annual) RDI

\section{Conclusions}

Within the watershed, both annual and seasonal distribution of drought found to be varying over the space and time. Being a long rainy season of the area, spring identified as season with extreme drought in 2001, 2002 and 2012-2013, which resulted from the influence of long dry winter season. Severe drought was observed in the years from 1986-1987, 1992, 1993, 2000 and 2004. In the year from 1986-2016, about 240 and 336 months were identified as months with extreme and severe drought respectively receiving rainfall below the mean of the observed years. Moderate and severe drought incidents occur more frequently as compared to the other 
drought category. With gradually declining trend of rainfall in the season, a varying drought frequency, intensity and magnitude were revealed in the watershed. Currently, changes in the intensity and frequency of drought events have significantly impacted pastoral society and their livelihood through determining water and pasture availability. Agro-ecologically and temporally varying drought events tends to weaken pastoralists' adaptive strategies where the drought of 2015/16, alone caused toll of death of their livestock due to severe drought in the area.

\section{Declarations}

Availability of data and materials: the data used or analyzed during the study are available from the corresponding author upon reasonable requests.

Competing Interests: The authors declare that they have no competing interests in this section Funding: This research was partially funded by Bule Hora University under the PhD research scholarship program for doctoral studies for the first author.

Authors contribution: The corresponding author contributed in data gathering, analysis and interpretation. The coauthors contributed in commenting and reframing the content of the research.

Acknowledgement: We thank Bule Hora University for the partial funding made for the first author in his $\mathrm{PhD}$ work and the National Meteorological Agency of Ethiopia for providing us Meteorological data

\section{List of Abbreviations}

MoA; Ministry of Agriculture

EEA: Ethiopian Environmental Authority

USAID: Unite States Agency for International Development

ENSO: El Niño Southern Oscillation

RDI: Reconnaissance Drought Index 
SPI: Standardized Precipitation Index

ASAL: Arid and Semi-Arid Lands

IFRCRCS: International Federation of Red Cross and Red Crescent Societies

ENMA: Ethiopian National Meteorological Agency

PET: Potential Eevapotranspiration

\section{References}

Abarufa Jatani (2011) Climate change and variability and its imp act on the livelihood of pastoralists: case study in dire woreda of Borana zone, oromia region

Abate, T, (2013). DTMA III Highlights for 2012/13: An Overview. Presented at the Drought Tolerant Maize for Africa (DMA) Annual Meeting, 23-27 September 2013, Nairobi, Kenya.

Abebe Arega, Arega Bazezew and Mehrete Belay Ferede (2020) Spatial and temporal drought incidence analysis in the northeastern highlands of Ethiopia; Geoenvironmental Disasters https://doi.org/10.1186/s40677-020-0146-4

Agnew, C.T and Chappell, A., (1999) Drought in the Sahel. Geo journal 48, 299-311, 1999

Alok Kumar M and Anil Kumar (2018). Investigating Rainfall Trend and Monitoring Meteorological Drought in a Himalayan Watershed of India; Geosciences Research, Vol. 3, https://dx.doi.org/10.22606/gr.2018.34002

Angasse A \& Oba G. (2007) Herder perceptions on impacts of range enclosure, crop farming, fire ban and bush encroachment on the rangelands of Borana, South western Ethiopia. Human Ecology 36, 201-215.

Araya and Stroosnijder, L (2011) Assessing drought risk and irrigation need in northern Ethiopia. Agric. For. Meteorol. 151, 425-436. 
Ayalew, D.; Tesfaye, K.; Mamo, G.; Yitaferu, B.; Bayu, W (2012) Variability of rainfall and its current trend in Amhara region, Ethiopia. Afr. J. Agric. Res., 7, 1475-1486.

Bekele Megersa (2013) Climate change, cattle herd vulnerability and food insecurity: Adaptation through livestock diversification in pastoral system of Ethiopia.

Boku Tache (2008) Pastoralism Under Stress: Resources, Institutions and Poverty among the Borana Oromo in Southern Ethiopia, PhD Thesis, Department of International Environment and Development Studies, Norwegian University of Life Sciences Norway

Boku Tache (2010) Participatory Impacts Assessment of Drought Reserve Areas in Guji and Borana Zones, Oromia Region. A report to Save the Children, Addis Ababa Boku Tache, (2008) Pastoralism Under Stress: Resources, Institutions and Poverty among the Borana Oromo in Southern Ethiopia, PhD Thesis, Department of International Environment and Development Studies, Norwegian University of Life Sciences, Norway.

Camberlin, P (1997) Rainfall anomalies in the source region of the Nile and their connection with the Indian summer monsoon. J. Clim., 10, 1380-1392. [CrossRef]

Davies, Buchanan, and Lambert (1991) Early warning in the Sahel and Horn of Africa: The state of the art. A review of the literature. Volume 1 of 3, Research Report No. 20. IDS, Brighton, U.K.

Degefu MA and Woldeamlak Bewuket (2014) Variability \& trends in rainfall amount and extreme event indices in the Omo-Ghibe River Basin, Ethiopia. Reg. Environ. Change 14, 799-810. https://doi.org/10.1007/s10113-013-0538-z.

Degefu MA, Bewket W (2015) Trends and spatial patterns of drought incidence in the OmoGhibe River basin, Ethiopia. GeografiskaAnnaler: Ser A, PhysGeograph 97(2):395-414. https://doi.org/10.1111/geoa.12080 
Degefu, M.A., Rowell, D.P., Bewket, W., (2017) Teleconnections between Ethiopian rainfall variability and global SSTs: observations and methods for model evaluation. Meteorol. Atmos. Phys. 129, 173-186. https://doi.org/10.1007/s00703-0160466- 9, 2017.

Dembele, M., and Zwart, S. (2016) Evaluation and comparison of satellite-based rainfall products in Burkina Faso, West Africa. Int. J. Remote Sens. 37 (17), 3995-4014. https://doi.org/10.1080/01431161.2016.1207258.

Desalegn Chemeda, Ashim D. G, and Mukand S B (2010) Drought Analysis in the Awash River Basin, Ethiopia, https://www.researchgate.net/publication/225623710. Accessed on June 13, 2019

Diro GT, Grimes DIF, Black E (2011b) Teleconnections between Ethiopian summer rainfall and sea surface temperature: part II. Seasonal forecasting. Clim Dyn 37:121131. doi:10.1007/s00382-010-0896-x

Ethiopian Environmental Authority, EEA (1998). Background information on drought and. Addis Ababa.Francis

Opiyo, Oliver Wasonga, Moses Nyangito, Janpeter Schilling and Richard Munang (2015) Drought Adaptation and Coping Strategies Among the Turkana Pastoralists of Northern Kenya. Int J Disaster Risk Sci (2015) 6:295-309

Gamachu D (1988) Some patterns of altitudinal variation of climatic elements in the mountainous regions of Ethiopia. MRD 8:131-138. doi:10.2307/3673439

Gebrehiwot, T.; van der Veen, A and Maathuis, B (2011) Spatial and temporal assessment of drought in the Northern highlands of Ethiopia. Int. J. Appl. Earth Obs. Geoinf. $13,309-321$.

Georgis, W.T., (1997) El Nino and Drought Early Warning in Ethiopia. Post-Doctoral Research Fellow National Center for Atmospheric Research, Boulder Colorado, USA 
Getachew Alem (2018) Drought and its impacts in Ethiopia; Weather and Climate Extremes 22, 24-35, www.elsevier.com/locate/wace

Ghosh KG (2019) Spatial and temporal appraisal of drought jeopardy over the Gangetic West Bengal, eastern India. Geoenviron Disas 6(1):1. https://doi.org/ 10.1186/s40677-018-0117-1 Accessed on October 15, 2020

Haied. N, A. Foufou, S. Chaab, M. Azlaoui, S. Khadri, K. Benzahia and I. Benzahia (2017) Drought assessment and monitoring using meteorological indices in a semi-arid region. International Conference on Technologies and Materials for Renewable Energy, Environment and Sustainability, TMREES17, 21-24 April 2017, Beirut Lebanon

Hesse C and MacGregor, J (2006) Pastoralism: Drylands' invisible asset? Developing a framework for assessing the value of pastoralism in east Africa. IIe D issue paper no 142 .

IFRCRCS, International Federation of Red Cross and Red Crescent Societies (2014) Early warning early action: Mechanisms for rapid decision making, Drought preparedness and responses in ASAL of Ethiopia, Kenya and Uganda and Eastern African region.

IPCC (2007). Climate change (2007) The physical science basis. In: Contribution of Working Group I to the Fourth Assessment Report of the Intergovernmental Panel on Climate Change. Cambridge, United Kingdom, New York, NY, USA. Cambridge University Press pp. 996

Jemai, Ellouze, Agoubi and Abida (2016) Drought intensity and spatial variability in Gabes Watershed, South-Eastern Tunisia; Journal of Water and Land Development No. 31 p. 63-72. DOI: 10.1515/jwld-2016-0037. 
Kiumars Zarafshani, Lida Sharafi, Hossein Azadi and Steven Van Passel (2016) Vulnerability Assessment Models to Drought: Toward a Conceptual Framework, A review paper, Journal of sustainability

Korecha, D.; Barnston, A.G. (2007) Predictability of June-September rainfall in Ethiopia. Mon. Weather Rev, 135, 628-650. [CrossRef]

Kumar, B.G. (1990) Ethiopian famines 1973-1985: A case-study. Polit. Econ. Hunger, 2, 173216.

Łabędzki L (2007) Estimation of local drought frequency in Central Poland using the Standardized Precipitation Index. Irrigation and Drainage J Int Commission Irrigation Drain 56(1):67-77 https://doi.org/10.1002/ird.285 Accessed on December 30, 2020

Masih, S. Maskey, F. E. F. Mussá, and P. Trambauer (2014) A review of droughts on the African continent: A geospatial and long-term perspective. Hydrology and Earth System Science, 18, 3635-3649

Mavhura. E, Siambabala. M, Andrew. C, and Desmond. M, (2013) Indigenous Knowledge, Coping Strategies and Resilience to Floods in Muzarabani, Zimbabwe. International Journal of Disaster Risk Reduction 5. Elsevier: 38-48.

Mishra, A. K and Singh, V.P (2011) Drought modelling: A review. J. Hydrol. 2011, 403, 157175.

Mohammed Y, Yimer F, Tadesse M, (2018) Variability and trends of rainfall extreme events in north east highlands of Ethiopia. Int J Hydro. 2(5):594-605. DOI: 10.15406/ijh.2018.02.00131

Mohammed Yimer (2015) Pastoral Development Pathways in Ethiopia; the Policy Environment and Critical Constraints Brief for GSDR 2015 
Ndlovu Brain (2011) Drought copying strategies at Mutasa district in Zimbabwe. A Master's Thesis at University of the Free State

Neha Karmeshu (2012) Trend Detection in Annual Temperature \& Precipitation using the Mann Kendall Test - A Case Study to Assess Climate Change on Select States in the North Eastern United States, University of Pennsylvania

Oloro Vahid McHugh (2006) Integrated water resources assessment and management in a drought-prone watershed in the Ethiopian highlands. Doctoral dissertation, Cornell University.

Oxfam (2008) Survival of the fittest. Pastoralism and climate change in East Africa. Oxfam Briefing Paper no. 116.

Peter D. Little, Kevin Smith, Barbara A. Cellarius, D. Layne Coppock and Christopher B. Barrett (2001) Avoiding Disaster: Diversification and Risk Management among East African Herders, Development and Change Vol. 32 (2001), 401 \pm 433 . Blackwell Publishers.

Rajib. M, Ashish. S, D. Nagesh, M. Asce and Kironmala. C (2013) Characterizing Drought Using the Reliability-Resilience-Vulnerability Concept. Indian Inst. of Science Bangalore on 06/14/13

Riché, B., Hachileka, E., Awuor, C. B., \& Hammill, A. (2009) Climate-related vulnerability and adaptive-capacity in Ethiopia's Borana and Somali communities: Final assessment report. London: Save the Children UK, Atlanta, GA: CARE International

Roop Singh, Mulugeta Worku, Solomon Bogale, Adrian Cullis, Alebachew Adem, Ben Irwin, Sheri Lim, Lorenzo Bosi, and Courtenay Cabot Venton (2016) Reality of Resilience: perspectives of the 2015-16 drought in Ethiopia, Resilience Intel; Issue No 6. 
Segele ZT, Lamb PJ (2005) Characterization and variability of Kiremt rainy season over Ethiopia. Meteorol Atmos Phys 89:153-180.doi:10.1007/s00703-005-0127-x

Seleshi and Camberlin, P (2006) Recent changes in dry spell and extreme rainfall events in Ethiopia. Theor. Appl. Climatol., 83, 181-191.

Seleshi Y, Demar'ee (1995) Rainfall variability in the Ethiopian and Eritrean highlands and its links with the southern oscillation index. Journal of Biogeography 22: 945-952 Seleshi Y, Zanke U (2004) Recent changes in rainfall and rainy days in Ethiopia. Int J Climatol 24:973-983. doi:10.1002/joc.1052

Shiau, J.T and Hsiao, Y. (2012) Water-deficit-based drought risk assessments in Taiwan. Nat. Hazards 64, 237-257.

Sujakhu, N., Ranjitkar, S.; Niraula, R.; Salim, M.; Nizami, A.; Schmidt, D.; and Xu, J., (2018) Determinants of livelihood vulnerability in farming communities in two sites in the Asian Highlands. Water Int., 43,165-182.

Tabari, H., Marofi, S., Aeini, A., Talaee, P.H., Mohammadi, K., (2011) Trend Analysis of Reference Evapotranspiration in the Western half of Iran; Agricultural and Forest Meteorology 151, 128-136

Temesgen (2010) Factors Affecting the Choices of Coping Strategies for Climate Extremes: The Case of Farmers in the Nile Basin of Ethiopia

Terefe, T.; Mengistu, G (2012) Spatial and temporal variability of summer rainfall over Ethiopia from observations and a regional climate model experiment climate model experiments. Theor. Appl. Climatol. 111, 665-681.

Thomas. T, K. Jaiswal, R. V. Galkate, T. R. Nayak (2015) Reconnaissance Drought Index based evaluation of meteorological drought characteristics in Bundelkhand International Conference on Emerging Trends in Engineering, Science and Technology (ICETEST-2015) 
Tsakiris G, Pangalou D, Vangelis H. (2007c) Regional drought assessment based on the reconnaissance drought index (RDI). Water Resour Manag 21(5):821-833.

Tsega Wolde-Georgis (1997) El Niño and Drought Early Warning in Ethiopia. Internet J. Afr.Stud.https://papers.ssrn.com/sol3/papers.cfm?abstract_id=1589710 (accessed on 16 May 2019).

USAID (2012) A Climate Trend Analysis of Ethiopia. Famine Early Warning Systems Network Informing Climate Change Adaptation Series; U.S. Department of the Interior

USAID (2016) El Niño in Ethiopia, A Real-Time Review of Impacts and Responses 20152016; USAID: Washington, DC, USA. Available online: https://www.agrilearning-ethiopia.org/wp-content/uploads/2016/06/AKLDPEl-Nino-Review-

March-2016, Accessed on 28 October 2019.

USGS (2012) A Climate Trend Analysis of Ethiopia. Famine Early Warning Systems (FEWS) Network informing Climate Change Adaptation Series. USGS Science for a Changing World. US Department of Interior. Fact Sheet 2012-3053. Rolla Publishing Service Center April 2012.

Viste E, Sorteberg A (2013) Moisture transport into the Ethiopian highlands. Int J Climatol 33:249-263. doi:10.1002/joc.3409

Viste, E.; Korecha, D.; Sorteberg, A (2013) Recent drought and precipitation tendencies in Ethiopia. Theor. Appl. Climatol. 112, 535-551. Web site: http://www.academia.edu.html. Accessed 20, July, 2019

Wing H. Cheung, Gabriel B. Senay and Ashbindu Singh (2008) Trends and spatial distribution of annual and seasonal rainfall in Ethiopia. Int. J. Climatol., DOI: 10.1002/joc.1623. 
Woldeamlak Bewket (2012) Climate change perceptions and adaptive responses of smallholder farmers in central highlands of Ethiopia, International Journal of Environmental Studies, 69:3, 507-523.

Woldeamlak Bewket and Declan Conway (2007) A note on the temporal and spatial variability of rainfall in the drought-prone Amhara region of Ethiopia. Int. J. Climatol. 27: 1467-1477, DOI: 10.1002/joc.1481

Yonas Tadesse (2019) Watershed-Based Rainfall variability and trends of extreme rainfall events in South East Awash Basin, Ethiopia. The International Journal of Social Sciences and Humanities Invention 6(06): 5524-5530, 2019 DOI: 10.18535/ijsshi/v6i6.07

Yuei-An Liou and Getachew Mehabie Mulualem (2019) Spatiotemporal Assessment of Drought in Ethiopia and the Impact of Recent Intense Droughts, Remote Sens. journal 2019, 11, 1828; doi:10.3390/rs11151828

Zarch M, Malekinezhad H, Mobin MH, Dastorani MT, Kousari MR (2011) Drought monitoring by Reconnaissance Drought Index (RDI) in Iran. Water Resource Manage 25:3485-3504.

Zenebe Gebreegziabher, Alemu Mekonnen, Rahel Deribe, Jonse Boka, and Samuel Abera (2016) Mapping Vulnerability to Climate Change of the Farming Sector in the Nile Basin of Ethiopia. A Micro-level Perspective, Discussion Paper Series. 
Figures

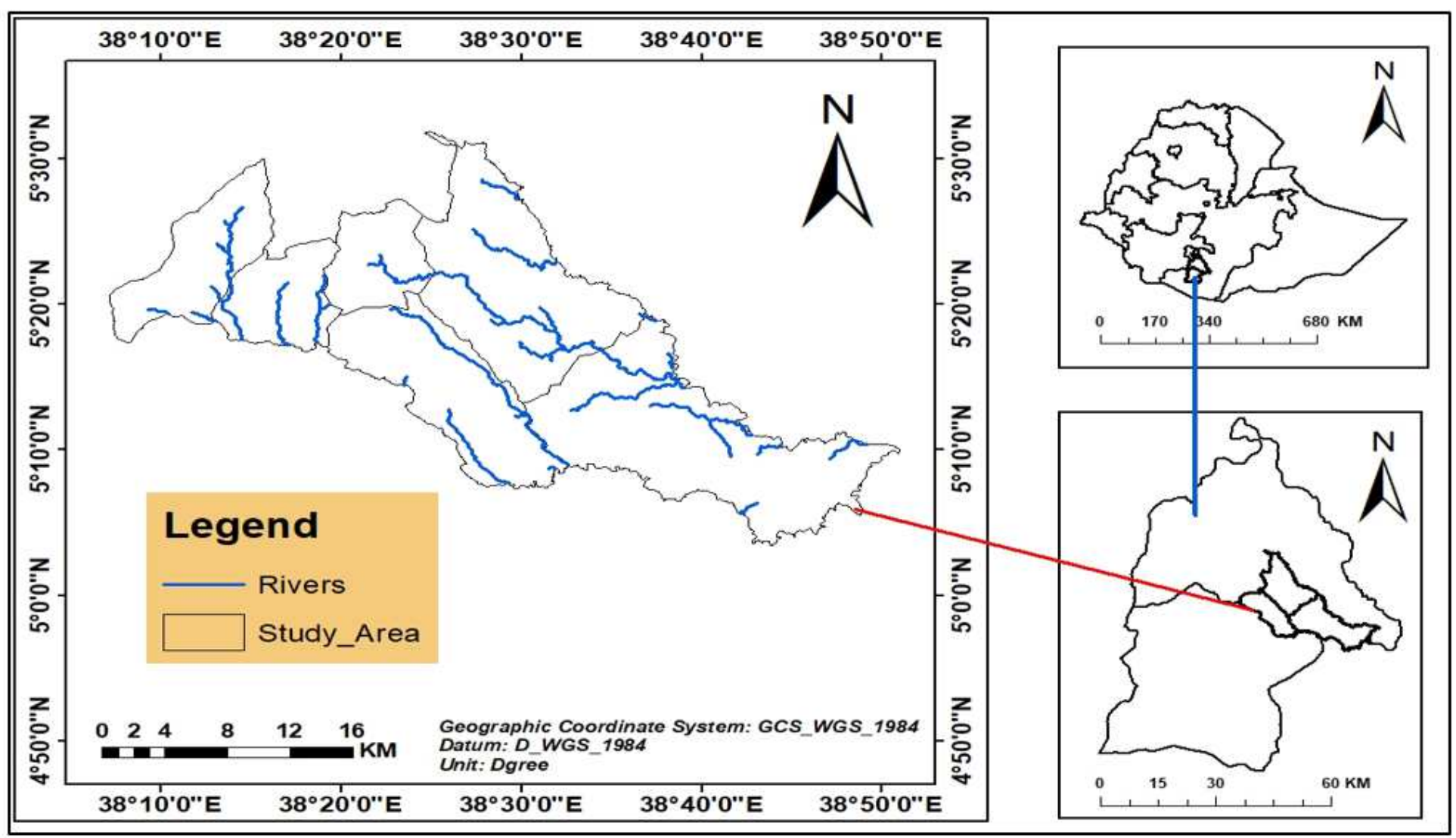

Figure 1

Location Map of the Study Area Note: The designations employed and the presentation of the material on this map do not imply the expression of any opinion whatsoever on the part of Research Square concerning the legal status of any country, territory, city or area or of its authorities, or concerning the delimitation of its frontiers or boundaries. This map has been provided by the authors. 


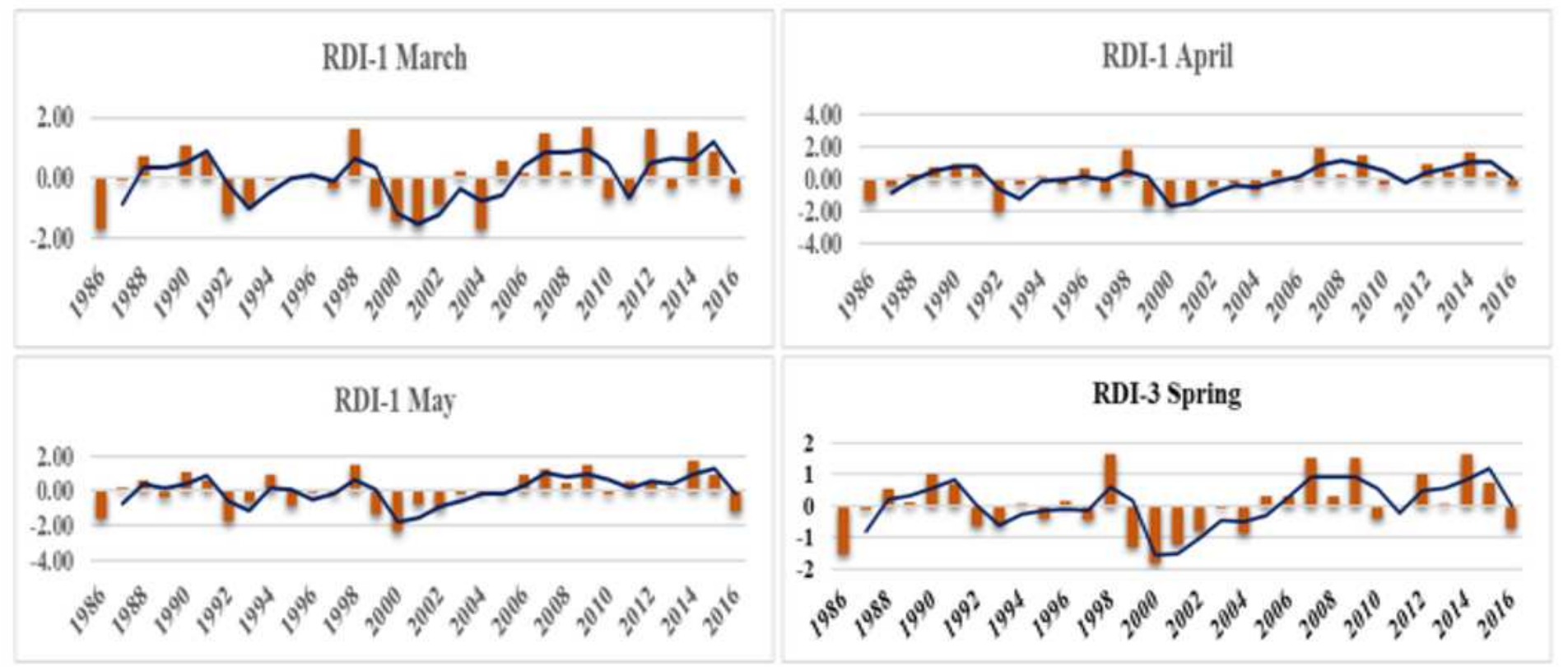

Figure 2

Month and Seasonal RDI for Spring

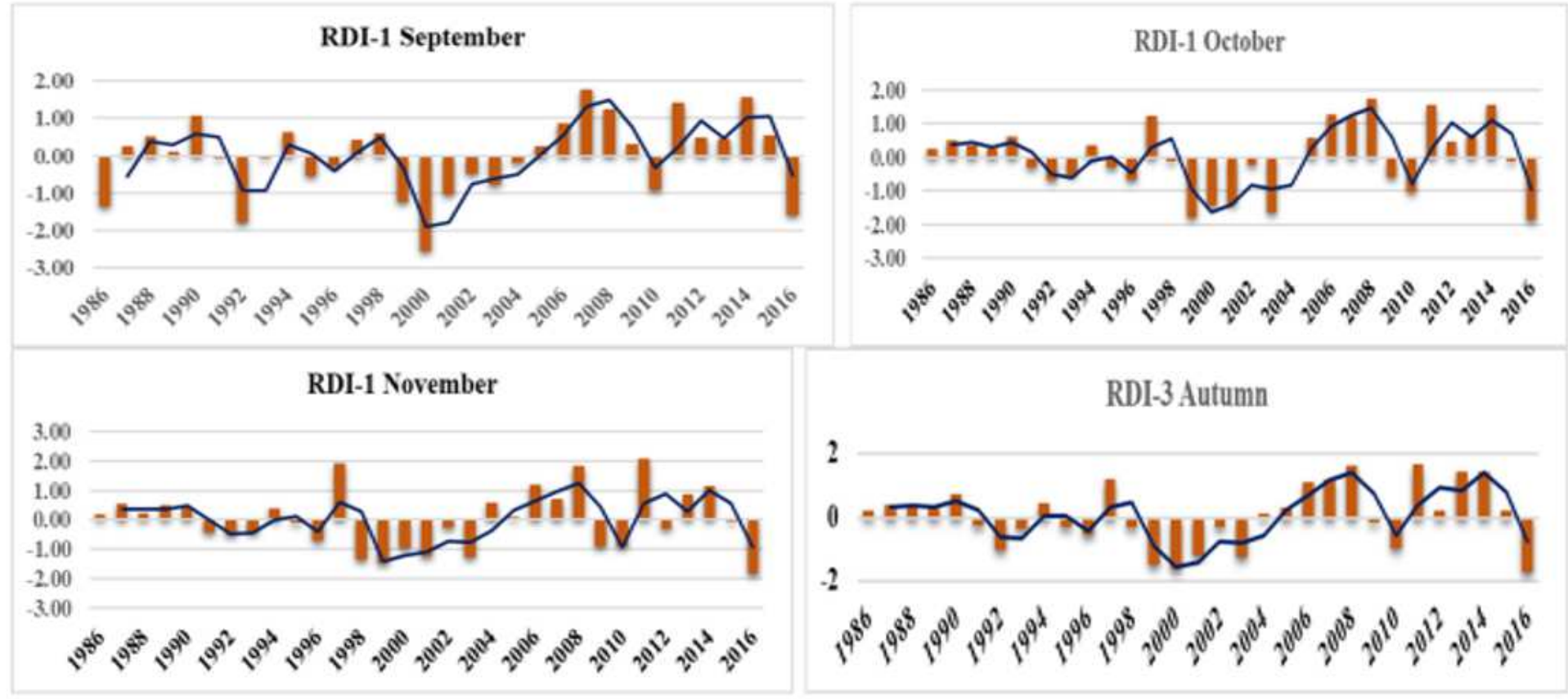

Figure 3

Month and Seasonal RDI for Autumn 


\section{2-Months RDI}

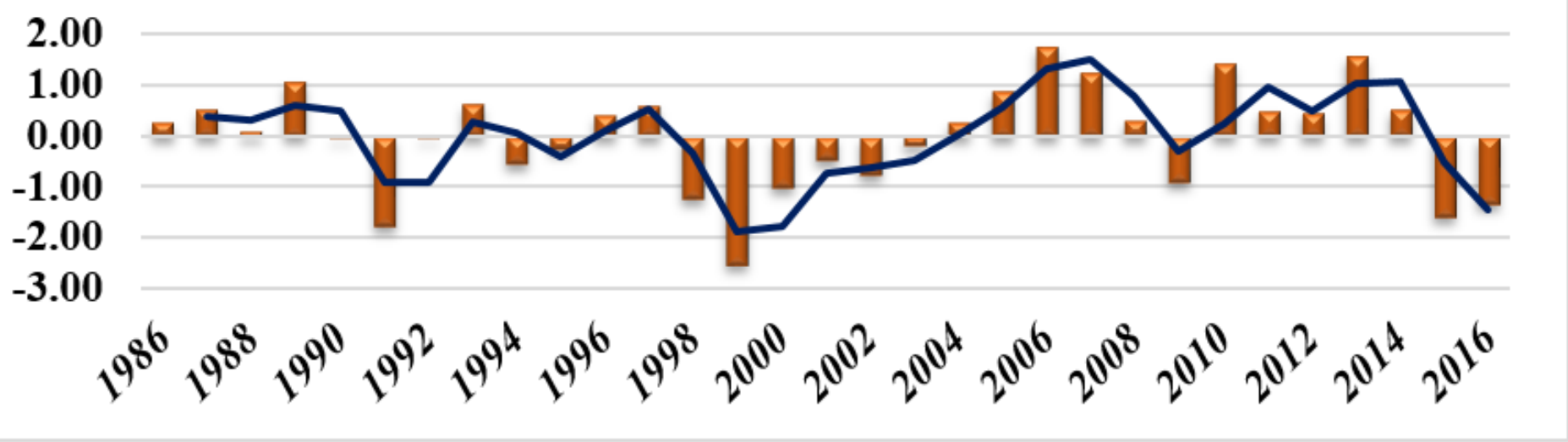

Figure 4

Month (Annual) RDI

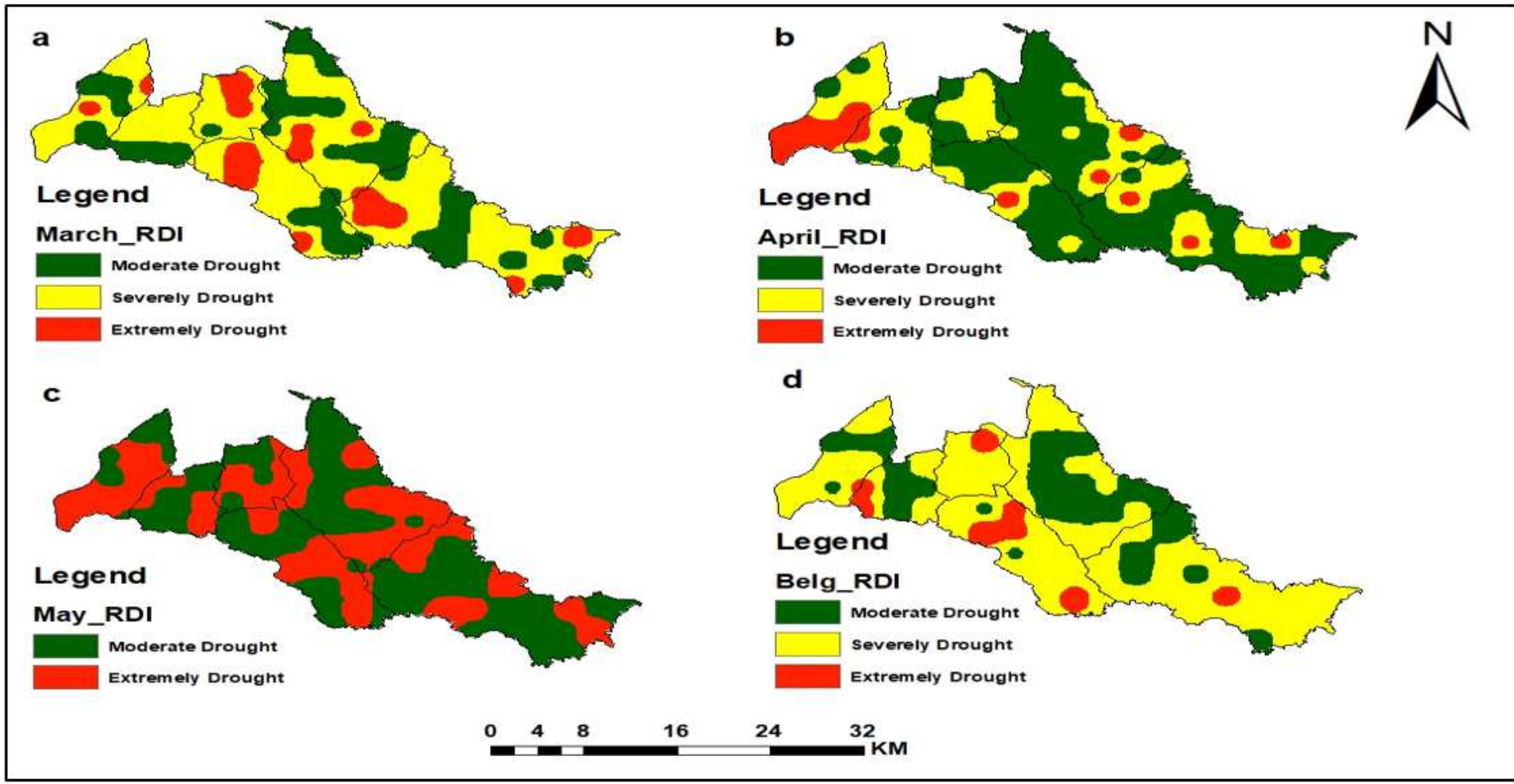

Figure 5

Spatial pattern of 1-month and 3-month (Spring Season) RDI Note: The designations employed and the presentation of the material on this map do not imply the expression of any opinion whatsoever on the part of Research Square concerning the legal status of any country, territory, city or area or of its authorities, or concerning the delimitation of its frontiers or boundaries. This map has been provided by the authors. 


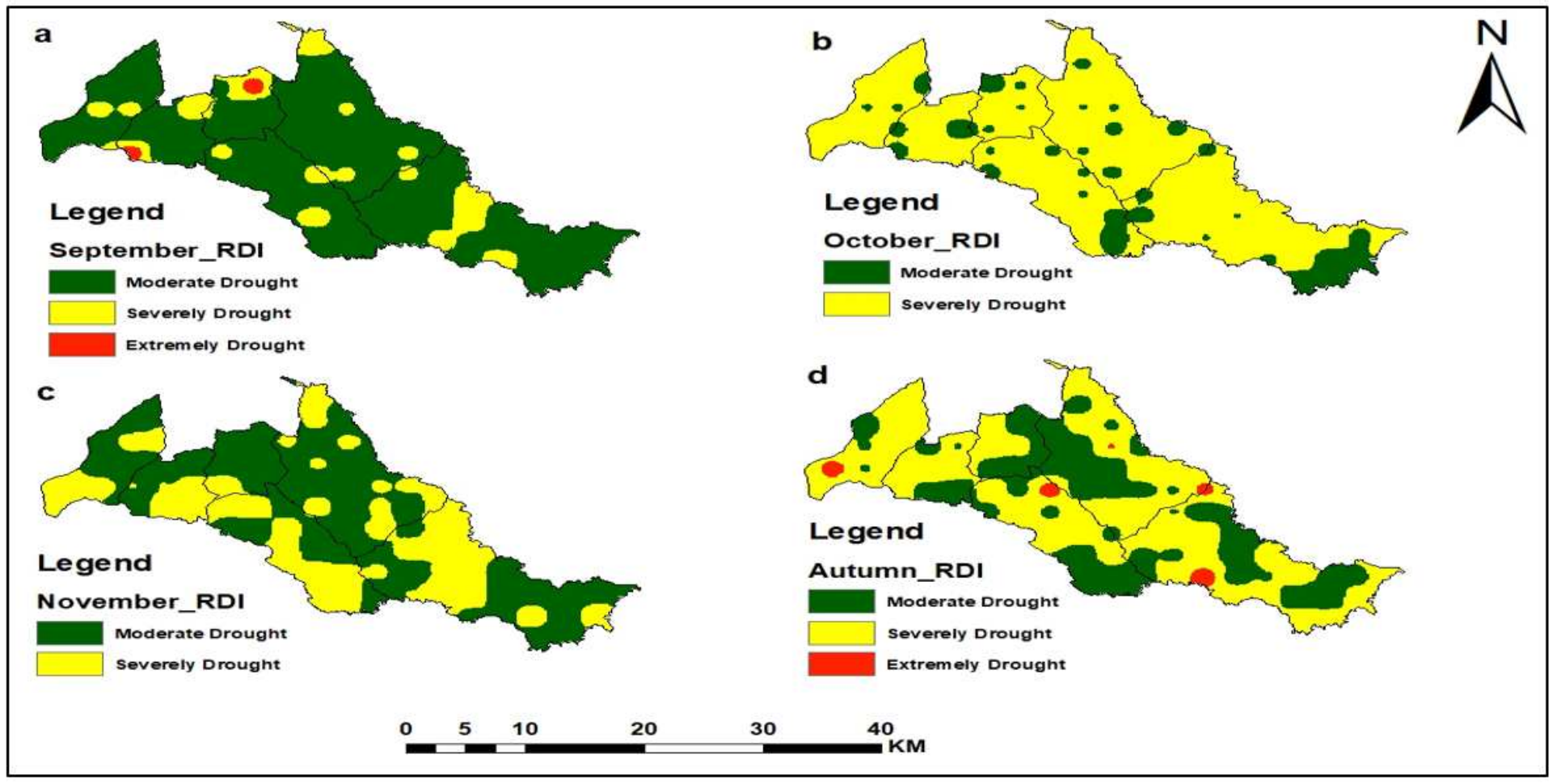

Figure 6

Spatial pattern of 1-month and 3-month (Autumn Season) RDI Note: The designations employed and the presentation of the material on this map do not imply the expression of any opinion whatsoever on the part of Research Square concerning the legal status of any country, territory, city or area or of its authorities, or concerning the delimitation of its frontiers or boundaries. This map has been provided by the authors.

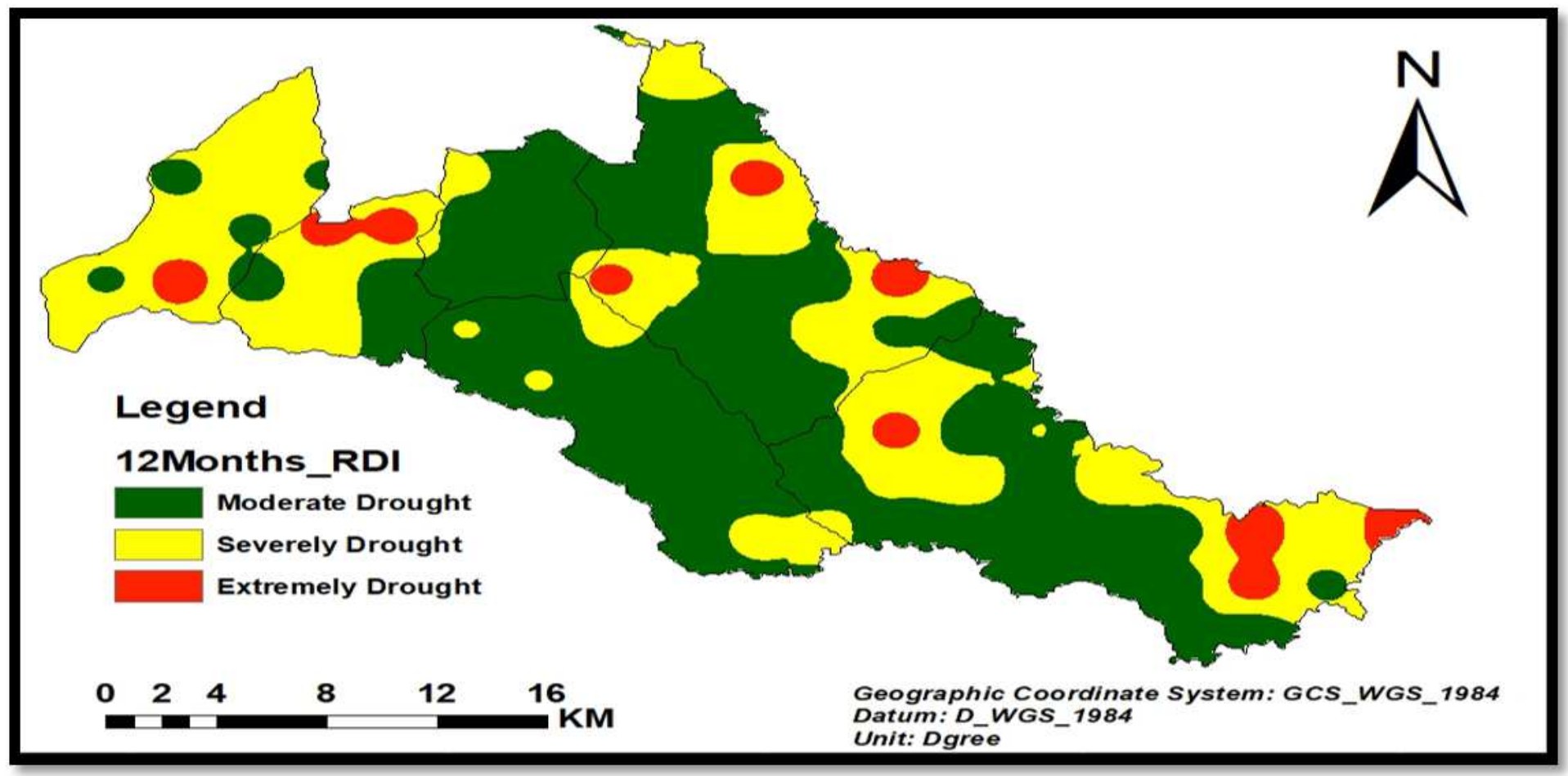




\section{Figure 7}

Spatial pattern of 12-month (Annual) RDI Note: The designations employed and the presentation of the material on this map do not imply the expression of any opinion whatsoever on the part of Research Square concerning the legal status of any country, territory, city or area or of its authorities, or concerning the delimitation of its frontiers or boundaries. This map has been provided by the authors. 